Л. В. Потапов, Б. Т. Жигмытов, Ц. Ж. Найданов. О стратегическом выравнивании социально-экономических условий развития субъектов и жителей России

УДК 336.02

DOI: $10.18101 / 2304-4446-2019-4-67-71$

\title{
О СТРАТЕГИЧЕСКОМ ВЫРАВНИВАНИИ СОЦИАЛЬНО-ЭКОНОМИЧЕСКИХ УСЛОВИЙ РАЗВИТИЯ СУБЪЕКТОВ И ЖИТЕЛЕЙ РОССИИ
}

\section{(c) Потапов Леонид Васильевич}

доктор экономических наук, профессор, ведущий научный сотрудник, Бурятский научный центр Сибирского отделения РАН Россия, 670000, г. Улан-Удэ, ул. Сахьяновой, 8

E-mail: orei.bnc@mail.ru

\section{(C) Жигмытов Баяр Тумурович}

кандидат политических наук, генеральный директор, Научно-просветительский центр им. Д. Банзарова

Россия, 670000, г.Улан-Удэ, ул. Шумяцкого, 14

E-mail: bayar_jigmytov@mail.ru

\section{(C) Найданов Цыренбал Жанчибдоржиевич} ведущий инженер, Бурятский научный центр Сибирского отделения РАН Россия, 670000, г.Улан-Удэ, ул. Сахьяновой, 8 E-mail: tsnaidanov@mail.ru

В статье рассмотрены вопросы стратегического выравнивания социальноэкономических условий развития субъектов и жителей Российской Федерации на 2020-2050 гг. Определены кластеры стратегического выравнивания социальноэкономического и научно-технологического развития субъектов России и большинства жителей Российской Федерации в Дальневосточном федеральном округе. Даны научно обоснованные рекомендации по подготовке новых федеральных и региональных законов и поправок в российское законодательство для выравнивания социальноэкономического развития субъектов Дальневосточного федерального округа, Востока России и всей Российской Федерации с целью сохранения и ускоренного развития самого крупного по территории государства планеты.

Ключевые слова: стратегическое выравнивание; ценология выравнивания; управление экономическим ростом; федеральное законодательство; Дальневосточный федеральный округ.

\section{Для цитирования}

Потапов Л. В., Жигмытов Б. Т., Найданов Ц. Ж. О стратегическом выравнивании социально-экономических условий развития субъектов и жителей России // Вестник Бурятского государственного университета. Экономика и менеджмент. 2019. № 4. С. 67-71.

В действующей Конституции Российской Федерации, в главе 1 «Основы конституционного строя», в статье 8 , п. 1 указано: «В Российской Федерации гарантируются единство экономического пространства, свободное перемещение това- 
ров, услуг, финансовых средств, поддержка конкуренции, свобода экономической деятельности ${ }^{1}$.

Ключевое требование современной Конституции России - единство экономического пространства российского государства, единство социальноэкономического развития всех субъектов Российской Федерации - одна из главных постоянных стратегических задач и служебных обязанностей органов государственного и муниципального управления, бизнеса и общества, основной стратегический принцип государственного, частного и общественного управления экономическим ростом в России ${ }^{2}$.

С целью реализации конституционного принципа единства экономического пространства в Российской Федерации необходимо подготовить и принять поправки к федеральному законодательству и к нормативным актам государственного и муниципального управления в России и в субъектах России.

Например, во всех субъектах Российской Федерации необходимо на государственном уровне установить единые тарифы инженерно и научно обоснованного регулирования потребления электроэнергии, тепловых и водных ресурсов для равномерного социально-экономического развития всей территории России как единого экономического пространства государства. Сегодня региональные тарифы на потребление электроэнергии, тепловых и водных ресурсов намного отличаются по субъектам России, их ценология не является открытой, научнотехнические обоснования региональных энерготарифов не публикуются открыто, составляя материальную базу для этнополитических протестов населения и предпринимателей - протесты выражаются в виде массового системного отъезда с территории Дальневосточного федерального округа молодого, трудоспособного и грамотного, высококвалифицированного населения, отказа многих крупных и средних инвесторов развивать новые промышленные объекты на этой территории.

Бесплатный дальневосточный гектар пустующей земли гражданам России для работы и проживания на Дальнем Востоке России - полезное стратегическое политическое решение руководства России, реализуемое с 2019 г. Для эффективной реализации такого федерального экономического решения необходимы новые федеральные инвестиции на Дальний Восток, чтобы, например, бесплатно (за счет федерального бюджета) подключить к линии электропередач на 220 вольт, к трассе или к скважине холодного водоснабжения новое хозяйство семьи дальневосточника. Это требует поправок в федеральное законодательство, чтобы более точно и надежно решать вопросы заселения трудоспособными жителями Востока России в течение ближайших трех лет, научно обоснованно заложив в федеральный и региональные бюджеты расходы для решения этих задач.

Для решения конкретных вопросов заселения Востока России необходимы новые политические, социально-экономические решения руководства Российской Федерации и её субъектов на Востоке России - такой мирный, масштабный процесс освоения крупнейшей части территории России развивается и решается впервые в истории планеты.

\footnotetext{
${ }^{1}$ Конституция Российской Федерации. М.: Экономика, 2016. 64 с.

${ }^{2}$ Конституция Республики Бурятия. Улан-Удэ: Республиканская типография, 2004. 84 с.
} 
Л. В. Потапов, Б. Т. Жигмытов, Ц. Ж. Найданов. О стратегическом выравнивании социально-экономических условий развития субъектов и жителей России

С этой целью авторы статьи предлагают новые политические и социальноэкономические решения по четырем кластерам выравнивания социальноэкономического развития и опережающего среднероссийский уровень экономического роста в субъектах Дальневосточного федерального округа.

Первый кластер - цифровизация экономики и социальной жизни населения субъектов Дальнего Востока России на основе результатов и рекомендаций научных исследований лауреата Нобелевской премии по экономике Василия Леонтьева и его научно-инженерной школы [3]. С помощью современных операторов суперкомпьютеров с инженерно-экономическим высшим образованием уже можно составлять подробные ежеквартальные электронные балансы экономики субъектов России, личных доходов трудящихся по всем отраслям и видам изделий и услуг в Республике Бурятия, ДВФО и всей России, используя подходы динамической обратной матрицы и «затраты - выпуск» [1]. По таким цифровым программам с большими массивами исходных данных можно точно просчитать и спрогнозировать валовый региональный доход и национальный доход, совершенствовать экономическую структуру региона, округа, Российской Федерации с учетом охраны окружающей среды, развития зеленой экономики на Востоке России.

Второй кластер выравнивания экономик субъектов Российской Федерации на Востоке - стратегическое планирование развития транспортной сферы - производства и эксплуатации наземного, водного и воздушного транспорта, развитие инфраструктуры транспорта - проектирование и строительство современной сети асфальтобетонных автомобильных и высокоскоростных (до 500 километров в час) железных дорог - Байкало-Амурской магистрали-2 и многих других трасс, водных причалов и портов, мостов, аэродромов и аэропортов по всей территории Востока России. В ценовой политике проезд пассажиров и провоз грузов на этой территории должен рассчитываться с учетом субсидий от доходов за природные ресурсы, добываемые на территории Востока России независимо от владельцев этих доходов по будущему федеральному закону, который обяжет две трети доходов за добываемые и обрабатываемые природные ресурсы с территории Востока России открыто для общества, на научной основе, планово выделять на социально-экономическое развитие населения и территории Востока России.

Третий кластер выравнивания социально-экономического развития в России для управления экономическим ростом на Востоке государства — выравнивание подушевого финансирования трудящихся всех профессий на этой территории. С этой целью все лицевые счета доходов работников должны анализироваться в единой цифровой системе субъекта России и контролироваться с помощью суперкомпьютера федерального округа по технологии и методам современной экономической кибернетики. В итоге поквартального анализа подушевого финансирования можно корректировать и выравнивать доходы работников учреждений культуры, образования, социальной поддержки и производства региона по сравнению с общероссийскими показателями, при условии улучшения объективных показателей работы каждого учреждения социальной сферы и производительности труда в производственных структурах на каждого работника и их непосредственных руководителей. 
Четвертый кластер выравнивания социально-экономического развития субъектов Российской Федерации в Дальневосточном федеральном округе - введение государственной системы ежемесячной выплаты каждому жителю округа всех возрастов в размере 10 МРОТ ежемесячно, пожизненно за счет доходов от реализации природных ресурсов и производства на их основе конечной продукции с высокой добавленной стоимостью на территории Востока России по аналогии с выплатами всем жителям соседней территории России - штата Аляска США, где департамент труда штата ежемесячно начисляет выплату за природные ресурсы, добываемые на территории штата в размере от трех тысяч долларов США каждому жителю Аляски, в результате чего в этом штате - нулевая миграция и другие позитивные экономические параметры социальноэкономического развития штата ${ }^{1}$.

Проблема решения стратегического выравнивания социально-экономического развития сегодня является актуальной как для Востока, так и для Запада России. Неравномерное социально-экономическое и научно-технологическое государственное и общественное управление развитием федеральных округов, субъектов России требует совершенствования действий федеральной и региональной, муниципальной власти в России на научной, доказательной основе в условиях острой планетарной экономической, военной, информационной конкуренции государств.

\section{Литература}

1. Леонтьев В. Экономические эссе. Теории, исследования, факты и политика: пер. с англ. М.: Политиздат, 1990. 415 с.: табл., схем.

\section{ON STRATEGIC EQUALIZATION OF SOCIO-ECONOMIC CONDITIONS} FOR THE DEVELOPMENT OF RUSSIAN ENTITIES AND POPULATION

\section{Leonid V. Potapov}

Dr. Sci. (Econ.), Prof., Leading Researcher,

Buryat Scientific Center SB RAS

8 Sakhyanovoy St., Ulan-Ude 670000, Russia

E-mail: orei.bnc@mail.ru

Bayar T. Zhigmytov

Cand. Sci. (Polit.), General Director,

Dorzhi Banzarov Research and Education Center

14 Shumyatskogo St., Ulan-Ude 670000, Russia

E-mail: bayar_jigmytov@mail.ru

Tsyrenbal Zh. Naydanov

Leading Engineer,

Buryat Scientific Center SB RAS

8 Sakhyanovoy St., Ulan-Ude 670000, Russia

E-mail: tsnaidanov@mail.ru

\footnotetext{
1 Материалы департамента труда штата Аляска, CША [Электронный ресурс]. URL: http://www.labor.state.ak.us (дата обращения: 30.08.2019).
} 
Л. В. Потапов, Б. Т. Жигмытов, Ц. Ж. Найданов. О стратегическом выравнивании социально-экономических условий развития субъектов и жителей России

The article deals with the issues of strategic equalization of socio-economic conditions for the development of Russian entities and population for 2020-2050. We have identified the clusters for strategic equalization of socio-economic, scientific and technological development of the constituent entities of Russia and the greater part of the population of the Far Eastern Federal District. The article provides scientifically grounded recommendations on preparation of new federal and regional laws and amendments to Russian legislation to equalize socio-economic development of the entities of the Far Eastern Federal District, the east of Russia and the entire Russian Federation, to preserve and accelerate growth of the largest nation state in the world.

Keywords: strategic equalization; cenology of equalization; economic growth management; federal legislation; the far Eastern Federal District. 